\title{
Autoinduction of tumor necrosis factor- $\alpha$ in FRTL-5 rat thyroid cells
}

\author{
Kouki Mori, Katsumi Yoshida ${ }^{1}$, Ayumi Komatsu, Jun-ichi Tani, \\ Yoshinori Nakagawa, Saeko Hoshikawa and Sadayoshi Ito \\ Division of Nephrology, Endocrinology and Vascular Medicine and ${ }^{1}$ Division of Rheumatology and Hematology, Tohoku University Graduate School of \\ Medicine, 1-1 Seiryo-machi, Aoba-ku, Sendai 980-8574, Japan \\ (Requests for offprints should be addressed to K Mori; Email: kokimori@mail.tains.tohoku.ac.jp)
}

\begin{abstract}
Tumor necrosis factor- $\alpha$ (TNF $\alpha)$ may play a role in the development of autoimmune thyroiditis such as Hashimoto's thyroiditis. In the present study, we examined whether TNF $\alpha$ induced its own expression in FRTL-5 rat thyroid cells. Lipopolysaccharide (LPS) markedly increased TNF $\alpha$ mRNA levels in FRTL-5 cells as assessed by semiquantitative RT-PCR. In addition, LPSstimulated cells released TNF $\alpha$ protein into the culture medium. Similarly, TNF $\alpha$ induced its own gene and protein expression in FRTL-5 cells as assessed by RT-PCR and metabolic labeling and immunoprecipitation of TNF $\alpha$. The autoinduction of TNF $\alpha$ gene was also observed in TNF $\alpha$-stimulated human thyroid epithelial cells. TNF $\alpha$ induction was specific to LPS and TNF $\alpha$ since interferon- $\gamma$ or amiodarone failed to increase TNF $\alpha$
\end{abstract}

mRNA levels in FRTL-5 cells. Human TNFa induced rat TNF $\alpha$ gene expression, indicating that type 1 TNF receptor (TNF-R) is involved in the autoinduction. TNF $\alpha$ did not increase either type 1 or type 2 TNF-R mRNA levels, suggesting that upregulation of TNF receptors is not involved in the autoinduction of TNFa. Although the biological significance of autoinduction of $\mathrm{TNF} \alpha$ remains unclear, our results suggest that thyroid epithelial cells may participate in the development of autoimmune thyroiditis through production of TNF $\alpha$. Furthermore, inhibition of TNF $\alpha$ production in the thyroid may represent a novel approach to mitigating inflammation in autoimmune thyroiditis.

Journal of Endocrinology (2005) 187, 17-24

\section{Introduction}

Tumor necrosis factor- $\alpha$ (TNF $\alpha)$ is a pleiotropic cytokine that acts as a central regulator of inflammation and immunity. This cytokine is detectable in thyroid tissues obtained from patients with Hashimoto's thyroiditis (Ajjan et al. 1996, Aust et al. 1996). In accordance, we and others have demonstrated enhanced TNF $\alpha$ gene expression in the inflamed thyroid of BioBreeding/Worcester $(\mathrm{BB} / \mathrm{W})$ rats (Mori et al. 1998, Bluher et al. 1999). Furthermore, TNF $\alpha$ augments interferon- $\gamma$ (IFN $\gamma$ )-induced class II major histocompatibility complex (MHC) antigen expression (Weetman \& Rees 1988, Zakarija et al. 1988). In FRTL-5 rat thyroid cells, TNF $\alpha$ induces interferon regulatory factor-1 (Mori et al. 1999), which plays a role in immune responses (Taniguchi et al. 1997). Taken together, these results suggest that TNF $\alpha$ may be involved in the development of autoimmune thyroiditis such as Hashimoto's thyroiditis.

While the majority of TNF $\alpha$ detected in inflamed thyroid tissues is produced by infiltrating inflammatory cells (Aust et al. 1996), studies demonstrate the production of TNFa by thyroid epithelial cells (Zheng et al. 1992, Mori et al. 1998). It may be possible that TNF $\alpha$ produced by infiltrating inflammatory cells induces its own expression in thyrocytes in the area of infiltration, since autoinduction of TNF $\alpha$ has been demonstrated in HL-60 human promyelocytic leukemia cells and in rat tracheal epithelial cells (Spriggs et al. 1990, Bader \& Nettesheim 1996). If so, thyrocyte-produced TNF $\alpha$ may stimulate infiltrating cells to aggravate inflammation in autoimmune thyroiditis. However, autoinduction of TNF $\alpha$ in thyroid epithelial cells has never been reported. In the present study, we examined whether TNF $\alpha$ induced its own expression in FRTL-5 cells.

\section{Materials and Methods}

\section{Reagents}

Recombinant rat IFN $\gamma$ and recombinant mouse TNF $\alpha$ were obtained from Genzyme (Cambridge, MA, USA). Recombinant human TNF $\alpha$ was purchased from R\&D Systems (Minneapolis, MN, USA). Lipopolysaccharide (LPS; Escherichia coli O55:B5) and amiodarone (AMD) were purchased from Sigma Chemical Co. (St Louis, MO, USA). $\alpha_{-}{ }^{32} \mathrm{P}-\mathrm{dATP}$ was purchased from New England Nuclear Corporation (Boston, MA, USA). 
${ }^{35}$ S-methionine (TRAN ${ }^{35}$ S-LABEL) was obtained from ICN Biomedicals (Irvine, CA, USA). Anti-p65 subunit of nuclear factor kappa $\mathrm{B}(\mathrm{NF}-\mathrm{\kappa B})$ and preimmune rabbit serum were purchased from Santa Cruz Biotechnology (Santa Cruz, CA, USA).

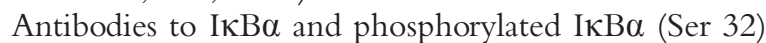
were obtained from New England Biolabs (Beverly, MA, USA). The chemiluminescence detection system (ECL) was purchased from Amersham Biosciences (Piscataway, NJ, USA). The Superscript preamplification system containing Superscript II reverse transcriptase was obtained from Gibco/BRL (Grand Island, NY, USA). All other chemicals and reagents were obtained from commercial sources and were of reagent or molecular biology grade.

\section{Cell culture}

FRTL-5 cells were obtained from ATCC (Rockville, MD, USA), proliferated in a thyrotropin (TSH)dependent manner and possessed all the properties previously described (Mori et al. 2001). Cells were grown in Coon's modified Ham's F12 medium supplemented with $5 \%$ calf serum containing bovine TSH $(1 \mathrm{mU} / \mathrm{ml})$, bovine insulin $(10 \mu \mathrm{g} / \mathrm{ml})$, human transferrin $(5 \mathrm{mg} / \mathrm{ml})$, glycyl-L-histidyl-L-lysine $(2 \mathrm{ng} / \mathrm{ml})$, somatostatin $(10 \mathrm{ng} / \mathrm{ml})$ and hydrocortisone $(0.36 \mathrm{ng} / \mathrm{ml} ; 6 \mathrm{H}$ medium). After cells approached confluence, cells were cultured for 7 days in media devoid of TSH (5H medium). This treatment allowed cells to be quiescent as shown previously (Mori et al. 2001). Human thyroid epithelial cells were obtained and cultured as previously described (Trieb et al. 1992) with modification. Normal thyroid tissues were removed from two patients who underwent thyroidectomy for papillary carcinoma. Informed consent was obtained from each patient and the study protocol was approved by the local ethics committee. The tissues were washed with PBS and minced into small pieces. They were digested with $1 \mathrm{mg} / \mathrm{ml}$ collagenase I (Sigma Chemical Co.) and $2.4 \mathrm{U} / \mathrm{ml}$ dispase II (Roche Diagnostics $\mathrm{GmBH}$, Penzbeg, Germany) in PBS at $37^{\circ} \mathrm{C}$ for $45 \mathrm{~min}$. This procedure was repeated for $75 \mathrm{~min}$ with fresh enzyme mixture. The resulting cell suspension was filtered through $100 \mu \mathrm{m}$ mesh and washed in $6 \mathrm{H}$ medium. Cells were cultured in $6 \mathrm{H}$ medium for $15 \mathrm{~h}$ followed by vigorous washing to remove non-adherent and loosely adherent cells. The remaining adherent cells were detached by treatment with trypsin EDTA solution (Gibco/BRL) and plated in culture flasks and 96-well flat-bottomed plates. More than 95\% cells were stained with serum containing a high titer of anti-thyroglobulin and anti-thyroid peroxidase antibodies from a patient with Hashimoto's thyroiditis (data not shown). The culture medium was changed twice a week. On the day of experiment, cells were incubated with test reagents for the indicated time and harvested for analyses. Treatment of cells did not result in cell detachment and had no effect on cell viability, as assessed by trypan blue exclusion.

\section{Extraction of soluble nuclear proteins}

Soluble nuclear proteins were obtained as previously described (Mori et al. 1999). In brief, FRTL-5 cells were washed twice with ice-cold PBS, and harvested in $1 \mathrm{ml}$ hypotonic buffer containing $10 \mathrm{mM} \mathrm{N}$-(2-hydroxyethyl) piperazine-N'-(2-ethane sulfonic acid; HEPES)-KOH, $\mathrm{pH} 7.9,10 \mathrm{mM} \mathrm{KCl}, 0.1 \mathrm{mM}$ EDTA, 0.1 mM EGTA, $1 \mathrm{mM}$ dithiothreitol (DTT), $0.5 \mathrm{mM}$ phenylmethylsulfonyl fluoride (PMSF), $10 \mu \mathrm{g} / \mathrm{ml}$ aprotinin, $10 \mu \mathrm{g} / \mathrm{ml}$ leupeptin, $1 \mathrm{mM} \mathrm{NaF}$ and $1 \mathrm{mM} \mathrm{Na} \mathrm{VO}_{4}$. After incubation on ice for $15 \mathrm{~min}$, cells were vortexed for $10 \mathrm{~s}$ in hypotonic buffer containing $0 \cdot 1 \%$ NP-40, followed by incubation on ice for $10 \mathrm{~min}$. Nuclei were pelleted by centrifugation, washed twice with hypotonic buffer and then the nuclear pellets were incubated at $4{ }^{\circ} \mathrm{C}$ for $30 \mathrm{~min}$ in hypertonic buffer containing $20 \mathrm{mM}$ HEPES-KOH, pH 7·9, 400 mM KCl, 1 mM EDTA, 1 mM EGTA, 1 mM DTT, $1 \mathrm{mM}$ PMSF, $10 \mu \mathrm{g} / \mathrm{ml}$ aprotinin, $10 \mu \mathrm{g} / \mathrm{ml}$ leupeptin, $1 \mathrm{mM} \mathrm{NaF}, 1 \mathrm{mM} \mathrm{Na}_{3} \mathrm{VO}_{4}$ and $20 \%$ glycerol. Supernatants were collected after centrifugation and stored at $-80{ }^{\circ} \mathrm{C}$ until use. Protein concentrations were measured by the Bradford method (Bradford 1976).

\section{Electrophoretic mobility shift assay (EMSA)}

The synthetic oligonucleotides, 5'-CAAACAGGGGGCT

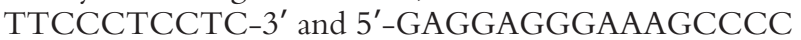

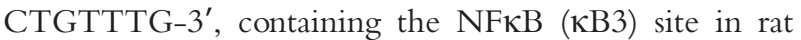
TNF $\alpha$ gene promoter (Nathens et al. 1997), were used for the detection of the protein-DNA complex by EMSA. The double-stranded probes were end-labeled using Klenow-DNA polymerase and $\alpha_{-}{ }^{32} \mathrm{P}-\mathrm{dATP}$. Nuclear proteins $(5 \mu \mathrm{g})$ were incubated with $40 \mathrm{fmol}{ }^{32} \mathrm{P}-$ labeled probe at $22^{\circ} \mathrm{C}$ for $30 \mathrm{~min}$ in buffer containing $10 \mathrm{mM}$ HEPES-KOH, pH 7.9, $100 \mathrm{mM} \mathrm{KCl,} 0.5 \mathrm{mM}$ EDTA, $0.5 \mathrm{mM}$ EGTA, $0.5 \mathrm{mM}$ DTT, $0.5 \mathrm{mM}$ PMSF, $10 \%$ glycerol, $0.05 \% \quad \mathrm{NP}-40$ and $2 \mu \mathrm{g}$ poly(dI-dC)-poly (dI-dC). The nucleoprotein complexes were resolved by nondenaturing electrophoresis in a 5\% polyacrylamide gel at $4{ }^{\circ} \mathrm{C}$ in buffer containing $45 \mathrm{mM}$ Tris- $\mathrm{HCl}, \mathrm{pH} 8.0$, $45 \mathrm{mM}$ boric acid and $1 \mathrm{mM}$ EDTA. Gels were dried and exposed to BioMax MS film (Eastman Kodak, Rochester, NY, USA) at $-80{ }^{\circ} \mathrm{C}$. For competition experiments, a 100-fold molar excess of the unlabeled oligonucleotides was added $15 \mathrm{~min}$ before incubation of nuclear extracts with radiolabeled probes. In supershift assays, nuclear proteins were incubated for $1 \mathrm{~h}$ at $22{ }^{\circ} \mathrm{C}$ with $1 \mu \mathrm{l}$ anti-p65 subunit of $\mathrm{NF \kappa B}$ or preimmune rabbit serum followed by addition of radiolabeled probes.

\section{Western blot analysis}

Cells were washed with ice-cold washing buffer containing $10 \mathrm{mM}$ sodium phosphate, $\mathrm{pH} 7 \cdot 4,137 \mathrm{mM} \mathrm{NaCl}$ 
Table 1 Length of amplified products, primer sequences and PCR cycles

\begin{tabular}{|c|c|c|c|}
\hline & Length & Sequence & Cycle \\
\hline \multicolumn{4}{|l|}{ Transcript } \\
\hline \multirow[t]{2}{*}{$\mathrm{TNF} \alpha$} & 687 & ATGAGCACGGAAAGCATGATC & 31 \\
\hline & & AGTAGACCTGCCCGGACTCCG & \\
\hline \multirow[t]{2}{*}{ TNF-R1 } & 322 & ACCAAGTGCCACAAAGGAACC & 29 \\
\hline & & TACACACGGTGTTCTGTTTCTCC & \\
\hline \multirow[t]{2}{*}{ TNF-R2 } & 252 & ATGAGAAATCCCAGGATGCAG & 33 \\
\hline & & ACAGACGTTCACGATGCAGGTG & \\
\hline \multirow[t]{2}{*}{ GAPDH } & 452 & ACCACAGTCCATGCCATCAC & 22 \\
\hline & & TCCACСAСССТGTTGСТGTA & \\
\hline
\end{tabular}

and $1 \mathrm{mM} \mathrm{Na}_{3} \mathrm{VO}_{4}$ and solubilized for $30 \mathrm{~min}$ at $4{ }^{\circ} \mathrm{C}$ in the lysis buffer containing $50 \mathrm{mM}$ Tris- $\mathrm{HCl}, \mathrm{pH} 7 \cdot 5$, $137 \mathrm{mM} \mathrm{NaCl}, 2 \mathrm{mM}$ EGTA, $1 \mathrm{mM}$ PMSF, $10 \mu \mathrm{g} / \mathrm{ml}$ aprotinin, $10 \mu \mathrm{g} / \mathrm{ml}$ leupeptin, $1 \mathrm{mM} \mathrm{Na} \mathrm{VO}_{4}, 1 \mathrm{mM}$ $\mathrm{NaF}$ and $0 \cdot 1 \%$ Triton $\mathrm{X}-100$. Supernatants were collected after centrifugation and aliquots containing $50 \mu \mathrm{g}$ protein were mixed with Laemmli sample buffer and separated by SDS-PAGE (Laemmli 1970). Proteins were transferred to a nitrocellulose membrane by electroblotting. After blocking with $1 \%$ BSA in Tris-buffered saline containing $0 \cdot 1 \%$ Tween 20 (TBST), membranes were incubated with rabbit polyclonal antibody to serine-phosphorylated I $\mathrm{B} \alpha$ $(1: 1000)$ overnight at $22{ }^{\circ} \mathrm{C}$. The membranes were washed and incubated with anti-rabbit $\operatorname{IgG}$ conjugated with horseradish peroxidase $(1: 2000)$ for $1 \mathrm{~h}$ at $22^{\circ} \mathrm{C}$.
Blots were visualized using the ECL detection system. After stripping, the membranes were reprobed with rabbit

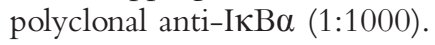

\section{$R T-P C R$}

Cells were washed twice with ice-cold PBS and total cellular RNA was isolated by the acid guanidiniumthiocyanate-phenol-chloroform extraction method of Chomczynski and Sacchi (1987), using Trizol (Gibco/ BRL). Four micrograms total RNA were reverse transcribed with Superscript II reverse transcriptase according to the manufacturer's instructions. All PCRs were performed in a $50 \mu \mathrm{l}$ reaction volume containing $1 \mu \mathrm{l}$ aliquots from each cDNA reaction, $10 \mathrm{pmol}$ of each upstream and downstream primer, 1.25 units Taq polymerase (Takara, Otsu, Japan), $0 \cdot 2 \mathrm{mM}$ of each dNTP, and $2 \mathrm{mM} \mathrm{MgCl}_{2}$. Amplification was performed at $94{ }^{\circ} \mathrm{C}$ for $30 \mathrm{~s}, 55^{\circ} \mathrm{C}$ for $30 \mathrm{~s}$, and $72^{\circ} \mathrm{C}$ for $60 \mathrm{~s}$ followed by a 5 -min extension at $72{ }^{\circ} \mathrm{C}$. The primer sequences, product length and PCR cycles shown in Table 1 were used for the detection of TNF $\alpha$, two types of TNF receptors, TNF-R1 and TNF-R2, and glyceraldehyde 3-phosphate dehydrogenase (GAPDH) gene expression in FRTL-5 cells. Primer pairs for rat TNF $\alpha$ span introns, and extra bands suggesting genomic DNA contamination were not seen. Human TNF $\alpha$ and human $\beta$-actin gene expression was determined using a human TNF $\alpha$ primer pair (BioSource International, Camarillo, CA, USA) and a human $\beta$-actin

\section{TNF $\alpha$ LPS TNF $\alpha$ LPS \\ $\begin{array}{llllllllllllll}P & 0 & 10 & 30 & 60 & 10 & 30 & 60 & C & \text { NS } & \text { p65 } & \text { C NS } & \text { p } 65\end{array}$}

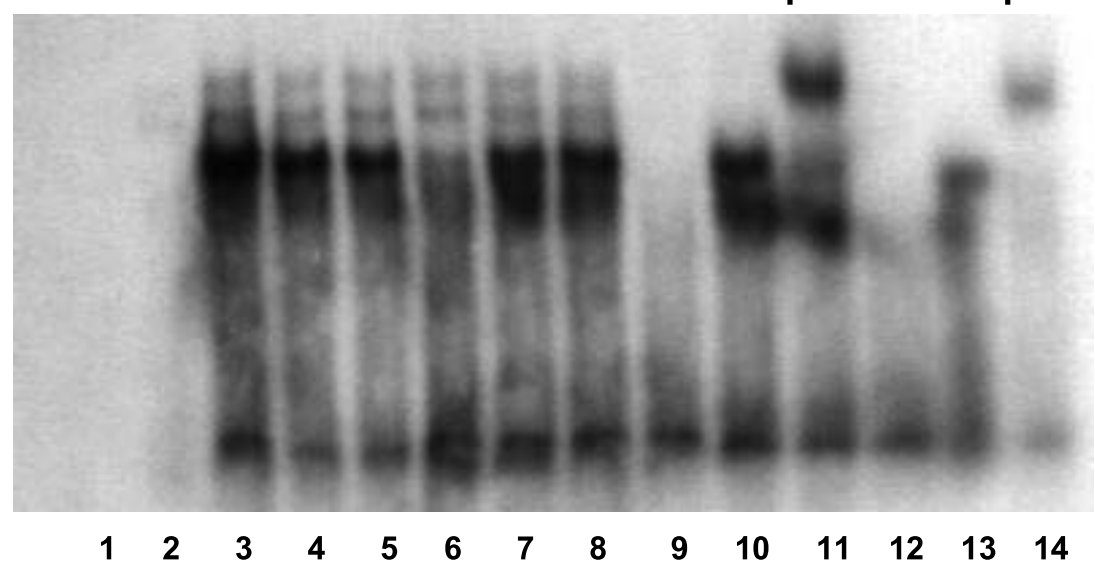

Figure 1 Effect of TNF $\alpha$ or LPS on nuclear NF-אB binding activity in FRTL-5 cells. Nuclear proteins were incubated with ${ }^{32} \mathrm{P}$-labeled synthetic oligonucleotides containing the NF- $\mathrm{KB}$ element $(\kappa B 3)$ of rat TNF $\alpha$ gene promotor and NF- $\kappa B$ binding activity was analyzed with EMSA. Cells were stimulated with $10 \mathrm{ng} / \mathrm{ml}$ mouse TNF $\alpha$ or $100 \mu \mathrm{g} / \mathrm{ml}$ LPS for the indicated times ( 0 , (unstimulated), 10, 30, $60 \mathrm{~min}$ ). $\mathrm{P},{ }^{32} \mathrm{P}$-labeled probe only and $\mathrm{C}$, a 100 -fold molar excess of unlabeled oligonucleotides were included as competitors. The complex formed in response to TNF $\alpha$ or LPS was supershifted by the anti-p65 subunit of NF-kB (p65), but not by preimmune rabbit serum (NS). The data presented are representative of three separate experiments. 


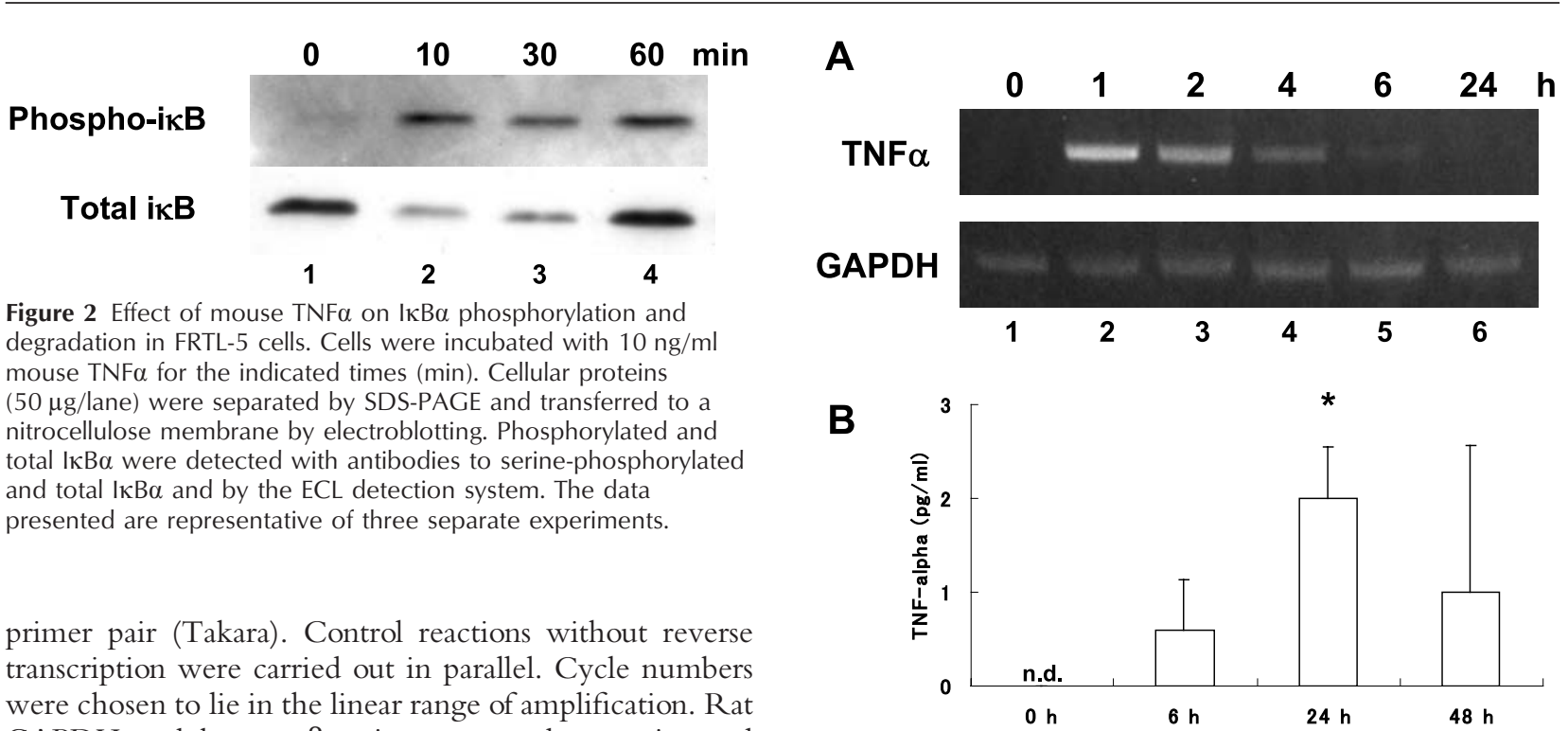
GAPDH and human $\beta$-actin were used as an internal standard to verify that equal amounts of RNA had been subjected to RT-PCR. PCR products were separated on $1.5 \%$ agarose gel and visualized with ethidium bromide. All PCR products were cloned into pGEM-T vector (Promega, Madison, IL, USA) and sequenced by the dideoxy chain termination method.

\section{Metabolic labeling and immunoprecipitation}

$\mathrm{TNF} \alpha$ protein production in TNF $\alpha$-stimulated cells was assessed by immunoprecipitation of ${ }^{35} \mathrm{~S}$-labeled TNF $\alpha$ (Zhou et al. 2000). Briefly, cells were washed with PBS and incubated in methionine-free RPMI (ICN Biomedicals) supplemented with L-glutamine, penicillinstreptomycin, $1 \%$ calf serum and ${ }^{35} \mathrm{~S}$-methionine (TRAN ${ }^{35} \mathrm{~S}-\mathrm{LABEL} ; 100 \mu \mathrm{Ci} / \mathrm{ml}$ ) for $24 \mathrm{~h}$ in the presence or absence of $50 \mathrm{ng} / \mathrm{ml} \mathrm{TNF} \alpha$. Cells were washed and lyzed in the lysis buffer. Samples were clarified by centrifugation and standardized to protein concentration. Cell extracts were precleared twice by incubating with protein A/G agarose (Santa Cruz Biotechnology). The samples were incubated with $5 \mu \mathrm{g}$ antibody to TNFa (Genzyme) or normal goat IgG overnight and protein A/G agarose was added for an additional $2 \mathrm{~h}$. The beads were washed 5 times and eluted in Laemmli sample buffer. The proteins were separated by SDS-PAGE and dried gels were subjected to autoradiography.

\section{TNFa ELISA}

TNF $\alpha$ released into the culture medium by FRTL- 5 cells treated with LPS for the indicated times was measured by a rat TNF $\alpha$ enzyme-linked immunosorbent assay (ELISA) kit (BioSource International), according to the manufacturer's instructions. The detection limits for rat TNF $\alpha$ were $0.7 \mathrm{pg} / \mathrm{ml}$. Human TNF $\alpha$ was measured by a human

Figure 3 (A) Induction of TNF $\alpha$ gene expression by LPS in FRTL-5 cells. Cells were incubated with $100 \mu \mathrm{g} / \mathrm{ml}$ LPS for the indicated times (h). Total RNA was reverse transcribed and the resulting CDNA was used for the PCR. The relative amounts of TNF $\alpha$ mRNA were normalized with GAPDH mRNA levels. The data presented are representative of three separate experiments. (B) Production of TNF $\alpha$ by LPS-stimulated FRTL-5 cells. Cells were incubated with $100 \mu \mathrm{g} / \mathrm{ml}$ LPS for the indicated times (h). TNF $\alpha$ levels in culture medium were determined using an ELISA kit. Data are the means of triplicate culture supernatants \pm S.D. and are representative of two separate experiments. n.d., not detectable. ${ }^{*} P<0.05$ compared with unstimulated cells $(0 \mathrm{~h})$.

TNF $\alpha$ ELISA kit (BioSource International) with the minimum detectable level of $0.1 \mathrm{pg} / \mathrm{ml}$. Data are the means of triplicate culture supernatants \pm S.D. and are representative of two separate experiments. Statistical analysis was performed using one-way ANOVA followed by Fisher's protected least significant difference test. A level of $P<0.05$ was considered statistically significant.

\section{Results}

EMSA was performed to verify that TNF $\alpha$ and LPS activate the transcription factor $N F-\kappa B$, which plays a central role in the TNF $\alpha$ - and LPS-stimulated intracellular signaling pathway in FRTL-5 cells. No NF- $\mathrm{KB}$ binding activity was detected in unstimulated cells (Fig. 1). Mouse TNF $\alpha$ induced a rapid and marked increase in NF- $\kappa B$ binding activity. Addition of a 100-fold molar excess of unlabeled oligonucleotides to the binding reaction completely blocked the binding activity. Furthermore, the complex formed in response to TNF $\alpha$ was supershifted by the anti-p65 subunit of NF- $\kappa B$, but not by preimmune rabbit serum (Fig. 1), indicating that activated NF- $\mathrm{KB}$ containing the p65 subunit was induced in response to TNF $\alpha$. Consistently, stimulation of cells with mouse 

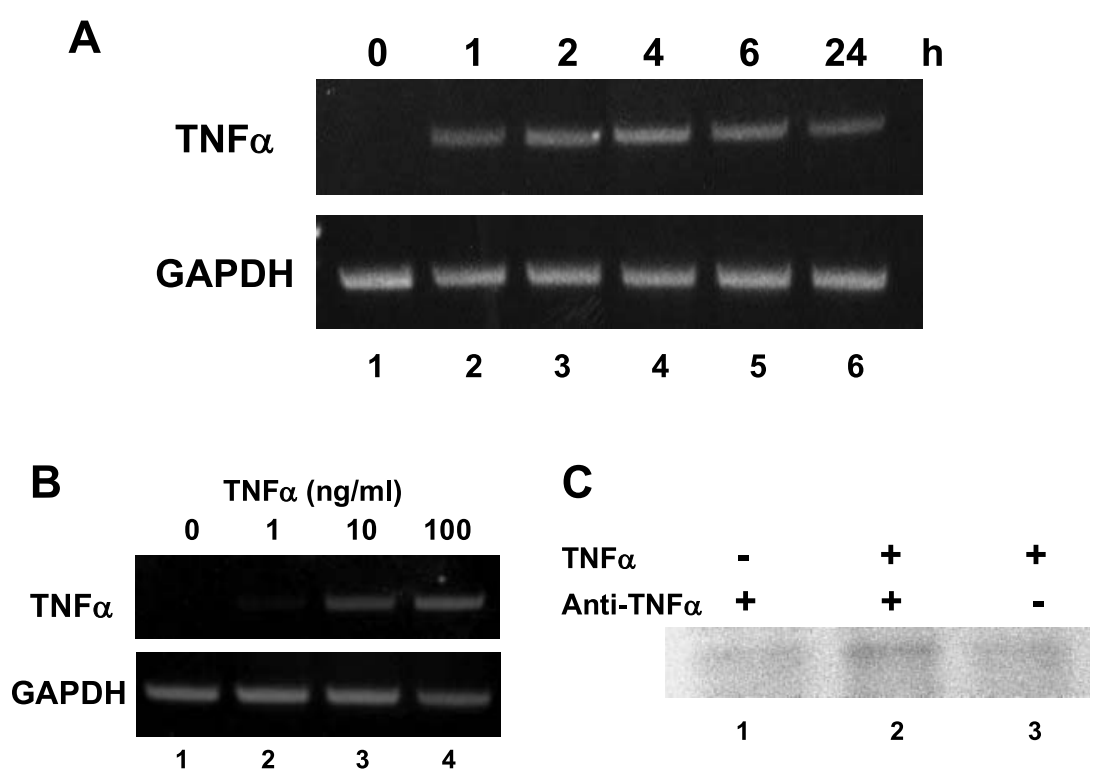

Figure 4 (A) Induction of TNF $\alpha$ gene expression in TNF $\alpha$-stimulated FRTL-5 cells. Cells were incubated with $10 \mathrm{ng} / \mathrm{ml}$ mouse TNF $\alpha$ for the indicated times (h). The data presented are representative of three separate experiments. (B) Dose-dependent induction of TNF $\alpha$ gene expression in mouse TNF $\alpha$-stimulated FRTL- 5 cells. Cells were treated with various doses of TNF $\alpha$ for $2 \mathrm{~h}$. The data presented are representative of three separate experiments. (C) De novo TNF $\alpha$ protein synthesis by TNF $\alpha$-treated FRTL-5 cells. Cells were stimulated with $50 \mathrm{ng} / \mathrm{ml}$ mouse TNF $\alpha$ and metabolically labeled with ${ }^{35} \mathrm{~S}$-methionine for $24 \mathrm{~h}$. Cells were lyzed, and TNF $\alpha$ molecules were immunoprecipitated using anti-TNF $\alpha$ antibody or normal goat IgG. Immunoprecipitates were subjected to SDS-PAGE under reducing conditions. Gels were dried and newly synthesized TNF $\alpha$ proteins were visualized by autoradiography. The data presented are representative of two separate experiments.

TNF $\alpha$ resulted in an increase in phosphorylated I $\mathrm{K} B \alpha$ levels and a concomitant decrease in total I $\mathrm{KB} \alpha$ levels at 10 and $30 \mathrm{~mm}$ after stimulation (Fig. 2). Similar to TNFa, LPS activated NF- $\kappa B$ (Fig. 1), consistent with previous studies (Guha \& Mackman 2001). Thus, we confirmed that the major signaling molecule, NF- $\mathrm{KB}$, was activated in response to TNF $\alpha$ and LPS in FRTL-5 cells.

TNF $\alpha$ gene expression in FRTL-5 cells was analyzed by semiquantitative RT-PCR. As shown in Fig. 3A, TNF $\alpha$ gene expression was not detected in unstimulated cells. Incubation of FRTL-5 cells with LPS, a very potent inducer of TNF $\alpha$, resulted in a rapid and marked increase in TNF $\alpha$ mRNA levels. As a result, FRTL-5 cells released very low but detectable levels of TNF $\alpha$ protein in response to LPS (Fig. 3B). Thus, we confirmed that FRTL-5 cells could produce TNF $\alpha$ in response to stimuli such as LPS.

Similar to LPS, TNF $\alpha$ clearly induced its own gene expression in FRTL-5 cells (Fig. 4A). Dose-dependent induction of the TNFa gene was observed in TNFatreated cells (Fig. 4B). We evaluated TNF $\alpha$ protein production by metabolic labeling and immunoprecipitation of newly synthesized TNF $\alpha$ protein. As shown in Fig. 4C, a modest but apparent increase in the levels of a $26 \mathrm{kDa}$ protein was observed in TNF $\alpha$-treated cells.
Thus de novo TNF $\alpha$ protein biosynthesis was induced in response to TNF $\alpha$ treatment in FRTL-5 cells. We confirmed that induction of TNF $\alpha$ gene was specific for LPS or TNF $\alpha$ since it was not observed over a $24-\mathrm{h}$ incubation period in cells treated with IFN $\gamma$ or AMD (data not shown), which induces interleukin (IL)-6 gene expression in the thyroid (Nakajima et al. 2001).

To determine whether autoinduction of TNF $\alpha$ gene was specific for FRTL-5 cells, human thyroid epithelial cells were stimulated with LPS or TNF $\alpha$. As reported previously (Zheng et al. 1992), human thyrocytes produced detectable levels of TNF $\alpha$ protein in response to LPS stimulation (Fig. 5A). In addition, TNF $\alpha$ induced its own gene expression in human thyroid cells (Fig. 5B). Thus, we confirmed that autoinduction of TNFa gene expression occurs in human thyrocytes as well as in FRTL-5 cells.

Human TNFa, which does not interact with the TNF-R2 in rodents (Lewis et al. 1991), induced TNFa gene expression (data not shown). We tested whether upregulation of TNF-Rs was involved in autoinduction of TNF $\alpha$ in FRTL-5 cells. As illustrated in Fig. 6, mouse TNF $\alpha$ failed to increase either TNF-R1 or TNF-R2 mRNA levels. 


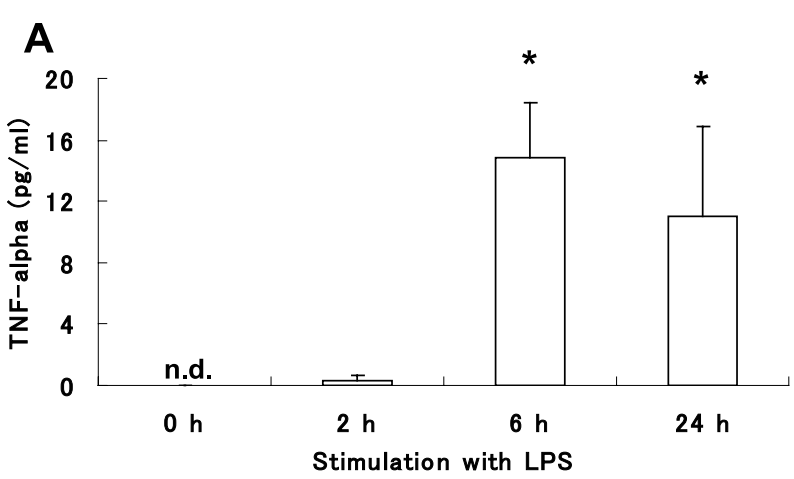

B

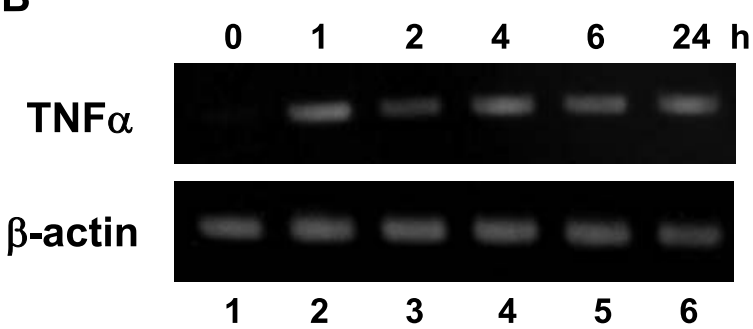

Figure 5 (A) Production of TNF $\alpha$ by LPS-stimulated human thyroid epithelial cells. Cells were incubated with $100 \mu \mathrm{g} / \mathrm{ml}$ LPS for the indicated times (h). TNF $\alpha$ levels in culture medium were determined using an ELISA kit. Data are the means of triplicate culture supernatants \pm S.D. and are representative of two separate experiments. n.d., not detectable. ${ }^{*} P<0 \cdot 05$ compared with unstimulated cells $(0 \mathrm{~h})$. (B) Induction of TNF $\alpha$ gene expression in TNF $\alpha$-stimulated human thyroid cells. Cells were incubated with $10 \mathrm{ng} / \mathrm{ml}$ human TNF $\alpha$ for the indicated times (h). The data presented are representative of three separate experiments.

\section{Discussion}

In the present study, we clearly demonstrate that TNF $\alpha$ induces its own expression in FRTL-5 cells, consistent with a previous observation that TNF $\alpha$ mRNA and protein levels are elevated in thyrocytes of patients with Hashimoto's thyroiditis (Zheng et al. 1992).

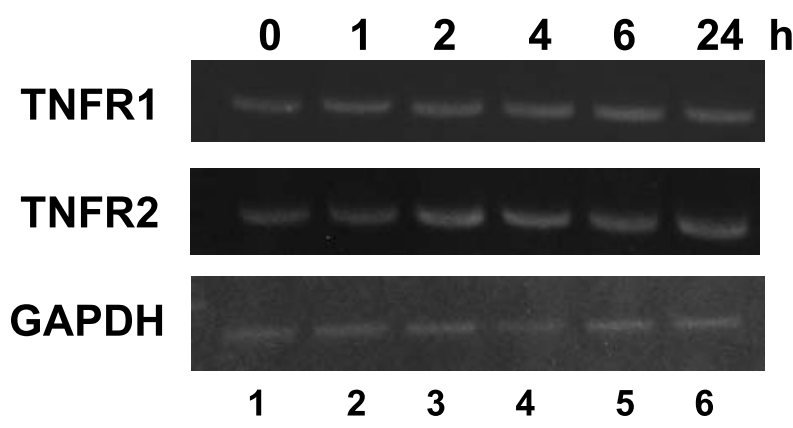

Figure 6 TNF-R1 and TNF-R2 gene expression in TNF $\alpha$-stimulated FRTL-5 cells. Cells were incubated with $10 \mathrm{ng} / \mathrm{ml}$ mouse TNF $\alpha$ for the indicated times (h). The data presented are representative of three separate experiments.
Autoinduction of TNF $\alpha$ has been reported in a variety of cells (Spriggs et al. 1990, Bader \& Nettesheim et al. 1996), but not in thyroid cells. Thus, the present study may be the first to show the autoinduction of TNF $\alpha$ in FRTL-5 cells. This phenomenon is not specific for this rat thyroid cell line since TNF $\alpha$ can induce its own gene expression in human thyroid epithelial cells. Although the biological significance of autoinduction of TNFa in the thyroid remains unclear, these findings suggest that thyrocytes may participate in the development of autoimmune thyroiditis through production of TNF $\alpha$. Furthermore, it may be possible that TNF $\alpha$ produced by infiltrating inflammatory cells such as activated macrophages and lymphocytes (Sariban et al. 1988, Aust et al. 1996) stimulates thyrocytes to produce TNF $\alpha$. This cytokine augments IFN $\gamma$-induced MHC class II antigen expression (Weetman \& Rees 1988, Zakarija et al. 1988) and induces cytokines such as IL-1 and IL-6 (Nawroth et al. 1986, Kikumori et al. 1998). Taken together, TNF $\alpha$ produced by thyroid epithelial cells may stimulate themselves and inflammatory cells in an autocrine and/or paracrine manner to facilitate immune reaction and inflammation in autoimmune thyroiditis. In accordance with this concept, Green et al. (1998) have demonstrated that TNF $\alpha$ produced in islets plays an important role in the development of autoimmune diabetes in nonobese diabetic mice. Accordingly, inhibition of TNF $\alpha$ action and production would be beneficial in order to suppress inflammation in autoimmune thyroiditis. This concept is supported by a recent study by Zaccone et al. (2002) showing that experimental autoimmune thyroiditis induced by immunization with thyroglobulin and LPS is inhibited by soluble TNF-R1.

In the present study, TNF $\alpha$ gene expression was clearly induced in FRTL-5 cells in response to LPS or TNF $\alpha$, as assessed by RT-PCR. In contrast, LPS- or TNF $\alpha$ stimulated FRTL-5 cells produced a very small amount of TNF $\alpha$ protein. Taken together, our results suggest that the FRTL-5 cell line may be a suitable model to determine the regulatory mechanism involved in TNF $\alpha$ gene expression, but not in TNF $\alpha$ protein synthesis, in the thyroid. Accordingly, establishment of more sensitive methods such as the immuno-PCR (Sanna et al. 1995) is clearly required to analyze TNFa biosynthesis in FRTL-5 cells. Alternatively, this issue could be addressed by the establishment of thyroid-derived cells that produce much higher amounts of TNF $\alpha$ protein. In this regard, human thyroid epithelial cells may be suitable since LPS-stimulated cells can produce larger amounts of TNF $\alpha$ than can FRTL- 5 cells as shown in Fig. 5A.

TNF $\alpha$ exerts its biological effects through binding to two distinct cell surface receptors, TNF-R1 and TNF-R2 (Lewis et al. 1991). Previous studies demonstrated that thyroid cells possess TNF receptors (Pang et al. 1989, 1996). However, TNF-R gene expression remained to be elucidated in TNF $\alpha$-stimulated thyroid cells. In the present study, we demonstrate detectable levels of 
TNF-R1 and TNF-R2 mRNA in unstimulated FRTL-5 cells. However, TNF $\alpha$ failed to increase transcript levels. These results suggest that TNF $\alpha$ induces its own expression without upregulating its receptor. The effects of TNF $\alpha$ on its receptor gene expression seem to be tissuespecific. In rat tracheal epithelial cells, TNF $\alpha$ downregulates TNF-R1 mRNA levels (Bader \& Nettesheim 1996). In contrast, this cytokine increases TNF-R1 transcripts in rat oligodendrocytes (Dopp et al. 1997). Finally, human TNFa, which binds to murine TNF-R1 but not to TNF-R2 (Lewis et al. 1991), induced TNF $\alpha$ gene expression, indicating that TNF-R1 is involved in autoinduction of TNF $\alpha$ in FRTL-5 cells.

In summary, we demonstrate that TNF $\alpha$ induces its own expression in FRTL-5 cells. Although the biological significance of this phenomenon remains to be elucidated, our results suggest that thyrocyte-produced TNF $\alpha$ may regulate immune and inflammatory reactions in the thyroid and thus may be involved in the development of autoimmune thyroiditis such as Hashimoto's thyroiditis. Furthermore, inhibition of TNF $\alpha$ production in the thyroid may represent a novel approach to mitigating inflammation in autoimmune thyroiditis.

\section{Acknowledgements}

This study was presented, in part, at the 74th Annual Meeting of the American Thyroid Association, Los Angeles, CA, USA in 2002. There is no conflict of interest that would prejudice the impartiality of this scientific work.

\section{References}

Ajjan RA, Watson PF, McIntosh RS \& Weetman AP 1996 Intrathyroidal cytokine gene expression in Hashimoto's thyroiditis. Clinical and Experimental Immunology 105 523-528.

Aust G, Heuer M, Lane S, Lehmann I, Hofmann A, Heldin NE \& Scherbaum WA 1996 Expression of tumor necrosis factor-alpha $(\mathrm{TNF}-\alpha)$ mRNA and protein in pathological thyroid tissue and carcinoma cell line. Clinical and Experimental Immunology 105 148-154.

Bader T \& Nettesheim P 1996 Tumor necrosis factor- $\alpha$ modulates the expression of its p60 receptor and several cytokines in rat tracheal epithelial cells. Journal of Immunology 157 3089-3096.

Bluher M, Krohn K, Wallaschofski H, Braverman LE \& Paschke R 1999 Cytokine gene expression in autoimmune thyroiditis in BioBreeding/Worcester rats. Thyroid 9 1049-1055.

Bradford MM 1976 A rapid and sensitive method for the quantitation of microgram quantities of protein utilizing the principle of protein-dye binding. Analytical Biochemistry 72 248-254.

Chomczynski P \& Sacchi N 1987 Single-step method of RNA isolation by acid guanidinium-thiocyanate-phenol-chloroform extraction. Analytical Biochemistrv 162 156-159.

Dopp JM, Mackenzie-Graham A, Otero GC \& Merrill JE 1997 Differential expression, cytokine modulation, and specific functions of type-1 and type-2 tumor necrosis factor receptors in rat glia. Journal of Neuroimmunology 75 104-112.
Green EA, Eynon EE \& Flavell RA 1998 Local expression of TNF $\alpha$ in neonatal NOD mice promotes diabetes by enhancing presentation of islet antigens. Immunity 9 733-743.

Guha M \& Mackman N 2001 LPS induction of gene expression in human monocytes. Cell Signaling 13 85-94.

Kikumori T, Kambe F, Nagaya T, Imai T, Funahashi H \& Seo H 1998 Activation of transcriptionally active nuclear NF- $\mathrm{KB}$ by tumor necrosis factor- $\alpha$ and its inhibition by antioxidants in rat thyroid FRTL-5 cells. Endocrinology 139 1715-1722.

Laemmli UK 1970 Cleavage of structural proteins during the assembly of the head of bacteriophage T4. Nature 227 680-685.

Lewis M, Tartaglia LA, Lee A, Bennet GL, Rice GC, Wong GHW, Chen EY \& Goeddel DV 1991 Cloning and expression of cDNAs for two distinct murine tumor necrosis factor receptors demonstrate one receptor is species specific. PNAS 88 2830-2834.

Mori K, Mori M, Stone S, Braverman LE \& DeVito WJ 1998 Increased expression of tumor necrosis factor- $\alpha$ and decreased expression of thyroglobulin and thyroid peroxidase mRNA levels in the thyroids of iodide-treated $\mathrm{BB} / \mathrm{W}$ or rats. European Journal of Endocrinology 139 539-545.

Mori K, Stone S, Khaodhiar L, Braverman LE \& DeVito WJ 1999 Induction of transcription factor interferon regulatory factor- 1 by interferon- $\gamma$ (IFN $\gamma$ ) and tumor necrosis factor- $\alpha$ (TNF $\alpha)$ in FRTL-5 cells. Journal of Cellular Biochemistry 74 211-219.

Mori K, Yoshida K, Tani J-I, Nakagawa Y, Hoshikawa S \& Ito S 2001 Double-stranded RNA-induced interferon regulatory factor-1 gene expression in FRTL-5 rat thyroid cells. Molecular and Cellular Endocrinology 184 77-86.

Nakajima K, Yamazaki K, Yamada E, Kanaji Y, Kosaka S, Sato K \& Takano K 2001 Amiodarone stimulates interleukin-6 production in cultured human thyrocytes, exerting cytotoxic effects on thyroid follicles in suspension culture. Thyroid 11 101-109.

Nathens AB, Bitar R, Davreux C, Bujard M, Marshall JC, Dackiw APB, Watson RWG \& Rotstein OD 1997 Pyrrolidine dithiocarbamate attenuates endotoxin-induced acute lung injury. American Journal of Respiratory Cell Molecular Biology 17 608-616.

Nawroth PP, Bank I, Handley D, Cassimeris J, Chess L \& Stern D 1986 Tumor necrosis factor/cachectin interacts with endothelial cell receptors to induce release of interleukin 1. Journal of Experimental Medicine 163 1363-1375.

Pang X-P, Hershman JM, Chung M \& Pekary AE 1989 Characterization of tumor necrosis factor- $\alpha$ receptors in human and rat thyroid cells and regulation of the receptors by thyrotropin. Endocrinology 125 1783-1788.

Pang X-P, Ross NS \& Hershman JM 1996 Alterations in TNF- $\alpha$ signal transduction in resistant human papillary thyroid carcinoma cells. Thyroid 6 313-317.

Sanna PP, Weiss F, Samson ME, Bloom FE \& Pich EM 1995 Rapid induction of tumor necrosis factor $\alpha$ in the cerebrospinal fluid after intracerebroventricular injection of lipopolysaccharide revealed by a sensitive capture immuno-PCR assay. PNAS 92 272-275.

Sariban E, Imamura K, Luebbers R \& Kufe D 1988 Transcriptional and posttranscriptional regulation of tumor necrosis factor gene expression in human monocytes. Journal of Clinical Investigation $\mathbf{8 1}$ 1506-1510.

Spriggs DR, Sherman ML, Imamura K, Mohri M, Rodriguez C, Robbins G \& Kufe DW 1990 Phospholipase A2 activation and autoinduction of tumor necrosis factor gene expression by tumor necrosis factor. Cancer Research 50 7101-7107.

Taniguchi T, Lamphierm MS \& Tanaka N 1997 IRF-1: the transcription factor linking the interferon response and oncogenesis. Biochimica et Biophysica Acta 1333 M9-M17.

Trieb K, Dorfinger K, Neuhold N, Selzer E, Wilfing A, Czernin S, Hermann M, Niederle B, Gessl A, Vierhapper H, Freissmuth M \& Grubeck-Loebenstein B 1992 Suramin affects differentiated and 
undifferentiated human thyroid epithelial cells in vitro. Journal of Endocrinology 134 505-511.

Weetman AP \& Rees AJ 1988 Synergistic effects of recombinant tumor necrosis factor and interferon-gamma on rat thyroid cell growth and Ia antigen expression. Immunology 63 285-289.

Zaccone P, Fehervari Z, Blanchard L, Nicoletti F, Edwards III CK \& Cooke A 2002 Autoimmune thyroid disease induced by thyroglobulin and lipopolysaccharide is inhibited by soluble TNF receptor type I. European Journal of Immunology $\mathbf{3 2}$ 1021-1028.

Zakarija M, Hornicek FJ, Levis S \& McKenzie JM 1988 Effects of $\gamma$-interferon and tumor necrosis factor- $\alpha$ on thyroid cells: induction of class II antigen and inhibition of growth stimulation. Molecular and Cellular Endocrinology 58 129-136.
Zheng RQH, Abney ER, Chu CQ, Field M, Maini RN, Lamb JR \& Feldmann M 1992 Detection of in vivo production of tumor necrosis factor-alpha by human thyroid epithelial cells. Immunology 75 456-462.

Zhou Z, Richard C \& Menard HA 2000 De novo syntheis of proteinase 3 by cytokine primed circulating human polymorphonuclear neutrophils and mononuclear cells. Journal of Rheumatology 27 2406-2411.

Received in final form 21 July 2005

Accepted 21 July 2005

Made available online as an Accepted Preprint

5 August 2005 